\title{
Diffuse C-Cell Hyperplasia
}

National Cancer Institute

\section{Source}

National Cancer Institute. Diffuse C-Cell Hyperplasia. NCI Thesaurus. Code C35407.

A non-neoplastic proliferation of morphologically bland C-cells with a diffuse growth pattern in the thyroid gland. 